\title{
Urban Farming During the Pandemic and Its Effect on Everyday Life
}

\author{
Maya Andini ${ }^{1}$, Ova Candra Dewi ${ }^{1}$, Annisa Marwati $^{2}$ \\ ${ }^{1}$ Department of Architecture/Faculty of Engineering, Universitas Indonesia, Indonesia \\ ${ }^{2}$ Department of Architecture/Faculty of Engineering and Design, Institut Teknologi dan Bisnis Ahmad Dahlan, \\ Indonesia \\ ova.candewi@ui.ac.id
}

\begin{abstract}
This study aims to see the effect of practicing urban farming in limited space in landed houses, especially during this pandemic. Pandemic forces us to stay at home at all times while continuing to do our daily activities of working and studying. This results in a shifting of time consumption we used to spend time commuting to work for other activities, including urban farming at home. Urban farming is the activity of growing and producing food in the city, as food is one of the basic needs of humans to survive. In addition to supporting food security within the area, it gives benefits also to the people's health and well-being, as well as the surrounding environment. The methods used in this study are exercising and observing the availability of space and its effect on people and living space (environment) from the literature review point of view and case studies. This study eventually finds that performing urban farming as a choice of activity is proven to be beneficial in maintaining people's health and wellbeing.
\end{abstract}

(C) 2021 IJBESR. All rights reserved.

Keywords: Urban Farming, Pandemic, Landed Houses, Limited Space, Happiness.

\section{Introduction}

Pandemic has changed our way of life as our dwelling transformed into the center of our daily activities when Work from Home (WFH) is advised. Therefore, having a home garden can be handy and beneficial during this pandemic time as people sometimes need to take a break from working and gardening can be one of the options. Urban farming has been the people's choice amid this COVID 19 pandemic which escalates the trend [1]. As urbanization keeps increasing year by year, big cities such as those located in the West Java province have become increasingly densely populated from $65.7 \%$ in 2010 to $78.7 \%$ in 2020 [2]. BPS (2020) data about the Percentage of Population in Urban Areas, predict that the urbanization rate is projected to reach $66.6 \%$ in 2035 at the national level. Close to nature and having an accessible green space proven to heal the stress and pressure of living in urban areas [3].

Preceding studies have shown that when someone faces a challenging life situation, it leads to a stressful feeling that later creates a negative effect on their health and wellbeing [4]. This current situation where we experience the COVID-19 pandemic plays a role that influences mental health conditions. The increased level of depression, anxiety, stress, and decreased level of life satisfaction are some examples of the pandemic impacts in our life. Studies have shown that being in nature and seeing all of the greeneries in the garden can give a positive effect on stress and mental health [5].

The literature that discusses the notion of urban farming itself varies. Urban agriculture is an 
intraurban or peri urban-based industry that grows and processes a range of food by using resources from within the area itself [6]. Others are from the opinion that growing, processing, and distributing food in or around the city is the key that defines urban agriculture [7]. Hence, urban farming is the practice of growing and producing food within the area of a city [8]. Products like fruits, vegetables, flowers, spices, or herbs are the horticulture components that one can implement in urban farming and are defined as a mixed cropping system that is identified as home gardens [9].

According to American psychologist Abraham Maslow in his paper "A Theory of Human Motivation" (1943), the diagram of needs hierarchy consists of five levels of human needs. The hierarchy of needs theory includes physiological needs as the basic needs on the bottom, followed by safety and security, belongingness and love need, esteem needs, and self-actualization at the top of the pyramid level [10]. Food is listed in the physiological needs as the main needs to be fulfilled before anything else.

Urban farming can also enhance food security, especially during this pandemic. Owning a home garden gives us the chance to produce and consume our food. It can also provide pleasure and satisfaction for ourselves as well as physical activity [11], [12]. Micro farming or small-scale agriculture is one of urban farming classification based on the location where this activity is practiced, usually done by a single family in a limited space within their house's yard [13]. Allocating some area either in the back or front area of the house for the garden is a start. However, in a certain condition, for instance, when you are living in a crowded house, maximizing every inch of the space can be the solution. Therefore, this study will focus on the effect of implementing urban farming in landed houses.

\section{Material and Methods}

Looking back at the aim of this study, the data is gained using two methods, namely questionnaire and study cases. The questionnaire is conducted to gain a bigger group of data. The data is taken within 5 days in December 2020, and 74 respondents are collected. Alongside, the study cases are performed to gain more specific data on two specific people who have done urban farming since before the pandemic. The interview is conducted by asking open-ended questions to the interviewees.

\subsection{Growing Food in the City}

Urban farming with its definition to grow food in the city is one of the keys to developing a sustainable food system within the city that will overcome the food security problems [14]. By growing our food, it can reduce expenses on food purchases from the market. Having access to sufficient and safe food that satisfies the dietary and food preference for an active and healthy life is what defines food security [15]. And growing our food can increase food security from within our neighborhood or the city where we live in. Referring to The Government Regulation No.68 of 2002 about Food Security, the condition of well-fulfilled food security for the household is suggested by the sufficiency of food in terms of its quantity, it is safe, affordable, and well-distributed.

Producing crops for personal consumption, education, revitalization, economic improvement, therapy, and business are some of the reasons behind the practice of urban farming [16]. Fresh products such as fruits, vegetables, flowers, spices, or herbs are the horticulture components that one can practice through urban farming. There is a wide range of urban agriculture that is commonly practiced. Residential landed houses, lofts, or apartments are examples of the space that can be used to practice micro-level farming. 

p-issn: 2581-1347 | e-issn: 2580-2607 | Pg. 51 - 62

Having land to grow food is the primary need for agricultural production [16]. Growing food can be practiced anywhere around the house. Other than the space, growing medium is also important, as it is the media or material where your plants grow in. What type of media is used will depend on which types of urban farming are implemented. There are four functions of a growing medium, namely providing physical support, aeration, a supply of water, as well as mineral nutrients [17].

Other than space and media, the environmental condition of the space is also important. Sun exposure is essential for plant growth. As the plants need the sun to grow, the space should be exposed to sunlight [18]. Other than sun exposure, constant access to water is also a vital aspect as it helps the plants to grow [19].

Various parts of the house can be used as a place to practice urban farming, such as front yard, backyard, balcony, rooftop, the wall of the house, fence, terrace, hallway, or deck [20]. The crops that will be produced can be cultivated by different systems of cultivation. Several types of farming techniques can be practiced at home, such as pot and polybag-farming, verticulture (vertical farming), hydroponic, aquaponic, and on the ground (Table 1).

Table 1: Types of Urban Farming based on the Space and Growing Media

\begin{tabular}{|l|l|}
\hline Types & Definition \\
\hline Pot \& Polybag & $\begin{array}{l}\text { A form of cultivation that uses a pot or } \\
\text { polybag (plastic bag used specifically for } \\
\text { cultivation) as the container to grow } \\
\text { crops. Can be applied in limited space as } \\
\text { it can be placed on the ground or flat } \\
\text { surface area. Suitable media are soil, rice } \\
\text { hulls, compost, manure, or sand. }\end{array}$ \\
\hline Verticulture & $\begin{array}{l}\text { A form of cultivation that is done } \\
\text { vertically by using a multilevel system } \\
\text { (standing verticulture, hanging or wall } \\
\text { verticulture or stack verticulture). } \\
\text { Suitable to be applied in limited land, } \\
\text { since the dimension can be adjusted based } \\
\text { on the preference or space availability. } \\
\text { Various types of plant containers can be }\end{array}$ \\
\hline
\end{tabular}

\begin{tabular}{|l|l|}
\hline Hydroponic & $\begin{array}{l}\text { used, such as pot and polybag, PVC pipe, } \\
\text { bamboo, wood, or board to create the } \\
\text { structure. Suitable media are soil or water. }\end{array}$ \\
\hline $\begin{array}{l}\text { A form of cultivation that uses water as } \\
\text { media; the water will be later added with } \\
\text { a nutrient solution. It is considered as the } \\
\text { popular type to be applied in limited } \\
\text { space, therefore suitable for people living } \\
\text { in the cities. This method minimizes the } \\
\text { area usage while increasing the number of } \\
\text { crops produced. This method is also } \\
\text { suitable for unfertile soil land areas. }\end{array}$ \\
\hline Aquaponic & $\begin{array}{l}\text { A form of cultivation that is a } \\
\text { combination of an interconnected } \\
\text { vegetable and fish cultivation system. } \\
\text { Uses a tank to circulate the water, } \\
\text { therefore requires an adequate amount of } \\
\text { land. Rack and fish ponds are essential for } \\
\text { these types. }\end{array}$ \\
\hline On the Ground & $\begin{array}{l}\text { A form of cultivation that is referred to as } \\
\text { conventional agriculture. It is an } \\
\text { agricultural system carried out directly on } \\
\text { the ground or land area. Using soil } \\
\text { (fertile) as the growing media and adding } \\
\text { fertilizers and pesticides to it. }\end{array}$ \\
\hline
\end{tabular}

Source: [20] Harianto, 2017; [21] Paeru \& Dewi, 2016; [22] Rinkesh, 2020; [23] Juniawati \& Hayuningtyas, 2020; [24] Felser, 2019

\subsection{Nature's Effect on People and Space}

A study conducted by Santo et al. (2016) showed that conducting urban farming activities can provide benefit to some human psychological aspects such as reducing stress, that called as therapeutic benefits [25]. A connection with nature can benefit human physical and also psychological aspects [26]. The pandemic and being at home most of the time results in people suffering stressful daily life. Another relevant study from Kaplan and Kaplan (1990) showed that people who suffer stressful daily life, anxiety, and fatigue can be restored by doing gardening activities [27]. Happiness, self-satisfaction, and productivity are examples of outcomes resulted from nature's benefit to the people's wellbeing (Table 2). 
Table 2: Effect on the People

\begin{tabular}{|l|l|}
\hline Indicator & Explanation \\
\hline Happiness & $\begin{array}{l}\text { Well fulfilled basic needs can improve } \\
\text { an individual's well-being that leads to } \\
\text { better health and happiness. Allocating } \\
\text { time to delve into natural space creates } \\
\text { a more calming and balanced mood. } \\
\text { Positive mood, emotion, and physical } \\
\text { well-being can be restored. }\end{array}$ \\
\hline Life satisfaction & $\begin{array}{l}\text { Satisfaction, which is also known as } \\
\text { happiness in general, is achieved when } \\
\text { someone's needs and wants are fulfilled } \\
\text { as a whole. Home gardening gives a } \\
\text { pleasant sense of fulfillment by looking } \\
\text { at the crops you have grown and cared } \\
\text { for. And by eating and growing food of } \\
\text { your own, it can give pleasure and a } \\
\text { sense of satisfaction. }\end{array}$ \\
\hline Productivity & $\begin{array}{l}\text { Spending an amount of time viewing } \\
\text { varieties of plants improves one's work } \\
\text { performance and increases the ability to } \\
\text { pay attention. This can lead to an } \\
\text { increased level of productivity. }\end{array}$ \\
\hline
\end{tabular}

Source: [28] Konner, 2002; [29] Mind, 2007; [30]

Delagran, 2016; [31] Ulrich et al.,1991; [32]

Veenhoven, 2012; [33] Sousa \& Lyubomirsky, 2001;

[19] Sofo \& Sofo, 2020; [34] Lohr et al., 1995; [35]

D’Alessandro, 2020

A green space in the house can do beyond brightening the view; it also purifies the air quality around the living space [19]. A study conducted by Sofo \& Sofo (2020) also stated that greeneries or a vegetable garden can cool the environment thanks to plant transpiration [19]. Having an outdoor space becomes more essential since people like to spend their time in the gardens. In addition to providing an added value, it also gives us pleasure [36].

The data is obtained from the questionnaire which is started by collecting respondents' personal data that includes age, gender, and the city where they live. This questionnaire is intended for people who are within the productive age which is, according to the Ministry of National Development Planning of the Republic of Indonesia (2001), in the range of 15 - 64 years old. After the questioning is completed, observation of their activities during this pandemic comes next which includes working from home. Furthermore, the respondents will be asked about the types and preferred urban farming activities and later the benefits of such activities for themselves and the space / environment.

While the questionnaire is intended to see the data on a larger scale, the data of the interviews are more specific. Both study cases have the same category, in which the person has created urban farming on their rooftop in an area less than $30 \mathrm{~m}^{2}$.

\section{Results and Discussions}

\subsection{Questionnaire}

The data is obtained from the questionnaire which is started by collecting respondents' data that includes age, gender, and the city where they live. This questionnaire is intended for people within the productive age which is, according to the Ministry of National Development Planning of the Republic of Indonesia (2001), within the age group range of 15 - 64 years old. After the questioning is completed, observation of their activities during this pandemic comes next, which includes working from home. Then, the respondents will be asked about the types and preferred urban farming activities and later the benefits of such activities for themselves and the space/environment.

The data collected from the questionnaire show that 17 people are in the range of 15-30 years old, 43 people in the range of $31-45$ years old, and 14 people in the range of 46-64 years old. Of all of the 74 respondents, 61 people are females and 13 people are males. Based on the cities where the respondents live, Jakarta occupies the highest rank with a total of 26 respondents. Regarding this pandemic situation, the data showed that 49 people worked outside the house before the pandemic, and now 32 people are fully working from 
home. As many as 64 people $(92.8 \%)$ stated that working from home has given them more leisure time.

According to the respondents' response, this leisure time can be spent doing other activities such as gardening or urban farming (mentioned by 49 respondents). This result is in line with the reviews that have been published which stated that urban farming is the people's choice of activity during the pandemic [1]. From 74 respondents, 43 people have started urban farming before the pandemic while 31 people initiated it after the pandemic. Because- of this pandemic, 42 people feel that their farming activities have become more intensive.

Based on the respondents' response on the reason behind their urban farming activity during this pandemic, 'to spend their free time' is the most popular answer with a total of 19 respondents. This corresponds to the review result stating that the free time during the pandemic can be spent by doing urban farming [37]. Allocating some times in the morning has become the respondents' favorite time to do urban farming, as mentioned by 62 people. As much as $90.5 \%$ of the respondents answered that they usually do urban farming with the family, either the children, siblings, or just whoever lives within the same house, while the rest like to do it just by themselves.

There is a wide range of urban farming types that are performed by the respondents in their houses (Figure 1). Pot/polybag farming is the most popular type among $41 \%$ (60) respondents. This relates to the fact that people living in the cities have narrow and limited space and growing plants in pot/polybags is commonly used. In terms of utilizing space in their house, the front yard and backyard are their first choices to do urban farming (Figure 2).

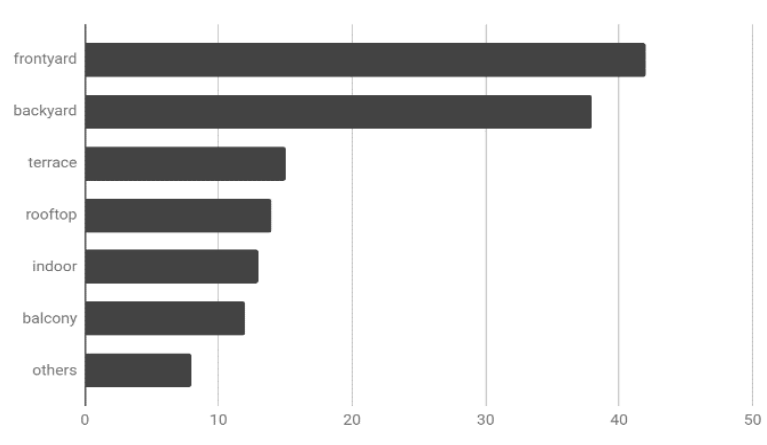

Source: (Data collection, 2020)

Figure 1: Types of Urban Farming Implemented

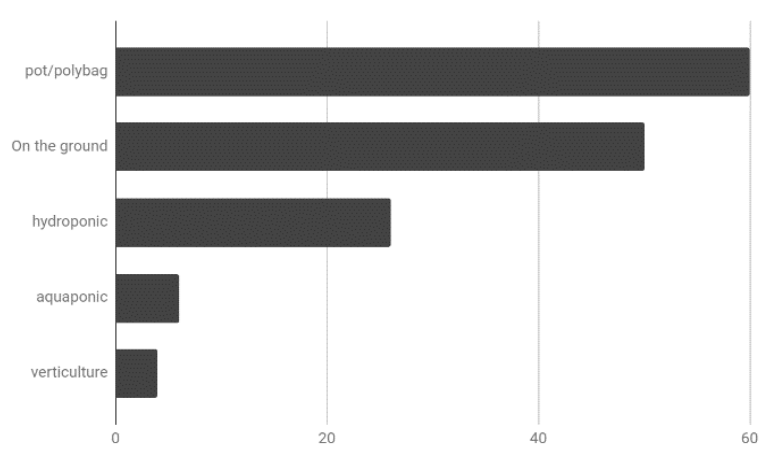

Source: (Data collection, 2020)

Figure 2: Location Within the Living Space

The front yard is the most popular place with a total of 42 respondents. As various locations are used for urban farming, the same applied to the surface area used. The surface area of land used by the respondents for urban farming activities in their houses varies, ranging from a smallscale of $1 \mathrm{~m} 2$ to a large-scale land of nearly 670 $\mathrm{m}^{2}$ (Figure 3). About 93.2\% (69 people) of the total respondents answered that they do urban farming for personal consumption. This correlate with the theory which stated that the reason behind the practice of urban agriculture is for personal consumption [16]. 
Table 3: Average Level of the Indicators Before and After Doing Urban Farming

\begin{tabular}{|l|c|c|c|}
\hline Indicator & Before & After & Difference \\
\hline Happiness & 7 & 8,8 & 1,8 \\
\hline Life-satisfaction & 7 & 8,7 & 1,7 \\
\hline Productivity & 7,2 & 8,6 & 1,4 \\
\hline
\end{tabular}

Source: (Data collection, 2020)

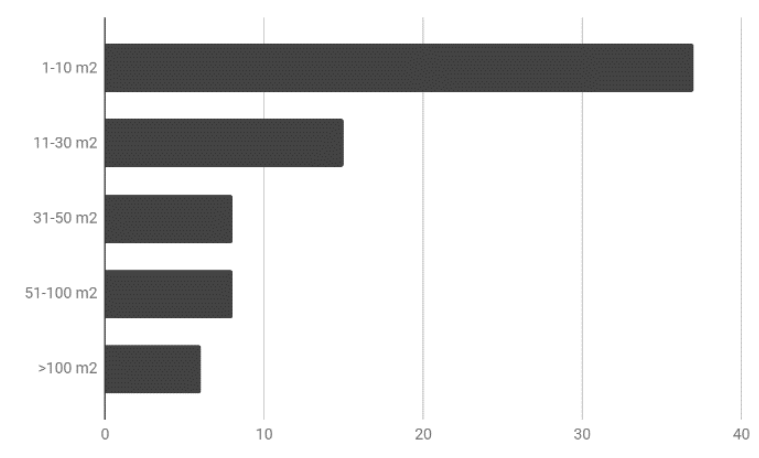

Source: (Data collection, 2020)

Figure 3: Area Used for Urban Farming

Among the respondents, 91.9\% agreed that they feel significant physical and mental changes in a more positive direction before and after doing urban farming activities, while $100 \%$ of respondents (74) agree that urban farming makes them feel healthier and increases their spirit. $97.3 \%$ agrees that urban farming can also reduce stress level. There are 3 indicators of urban farming's effect on the people, namely happiness, self-satisfaction, and productivity [31], [19], [30]. These indicators are being analyzed further through the questionnaire (Table 3).

As the target respondents are those who do urban farming, the starting number of all indicators is around 7. This may be considered a quite high value and aligned with the theory which stated that being in nature can give a positive effect [31]. Table 3 showed that before doing urban farming, the overall level of happiness felt by the respondent is 7 and changed to 8.8 afterward. This showed that there is an increased level of happiness of 1,8 . Emotional wellbeing can be restored by being in nature or even just by watching scenes of nature [30]. Referring to the data, 58 people enjoyed an increased level of happiness, 14 people experienced no changes, and 2 people had decreased level of happiness.

In terms of self-satisfaction, Table 3 showed that before doing urban farming, the overall level of self-satisfaction is 7 and 8.7 afterward. This showed that there is an increased level of satisfaction of 1,7. Doing urban farming can improve our overall life-satisfaction [19], [11]. Referring to the data, 56 people had an increased level of self-satisfaction, 17 people had no changes, and 1 person had a decreased one.

Table 3 also showed that before doing urban farming, the overall level of productivity is 7.2 and 8.6 afterward. This showed that there is an increased level of productivity of 1,4. Being in the garden can maintain work productivity, as it increases our ability to pay attention [26]. Referring to the data, 50 people experienced an increased level of productivity, 22 people had no changes, and 2 people had a decreased one. Considering that all level indicators before urban farming is 7 and changed to between 8.6 - 8.8 afterward, this suggests an increased level.

Among the respondents, $98.6 \%$ ( 73 people) also agreed that doing urban farming activities at your home can beautify the space as it is filled with greeneries. They can brighten the view and also purify the air quality within the environment [19]. As many as 97.3\% (72 people) became more active with nature through urban farming.

The questionnaire is intended to see the data on a larger scale while more specific data to be obtained through interviews. These data include the garden space size and the configuration, planting media used for each of the plants, as well as environmental conditions. Both study cases have the same category, where 
people do the urban farming on their rooftop area of less than $30 \mathrm{~m}^{2}$.

\subsection{Study Case}

\subsubsection{Case Study 1}

The first garden utilizes an unused area on the rooftop of a house or usually called a roof terrace. The house itself is a two-level house located in Cirendeu, Tangerang Selatan area. The planter or defined as the one who grows the plants is a 64-years old woman named Tuti. She lives in the house together with other 5 family members. She is currently unemployed and has been doing this urban farming gardening since the pandemic started to spend time. The type of urban farming utilizes things that are readily available at home. It is a combination of cultivating plants using pots and polybags, hydroponic, as well as vertical stack garden.

The unused space is utilized for urban farming within the area of the house, which is located on the rooftop. The area itself has a dimension of 4 $\mathrm{m} \times 6 \mathrm{~m}$ with a total size of $24 \mathrm{~m} 2$ (Figure 4). It is filled with various types of plants, ranging from herbs, spices, vegetables, and fruits. Before the pandemic, the rooftop is an empty, unused space. The owner tries to maximize the use of space by planting greeneries for her to enjoy in the evening.

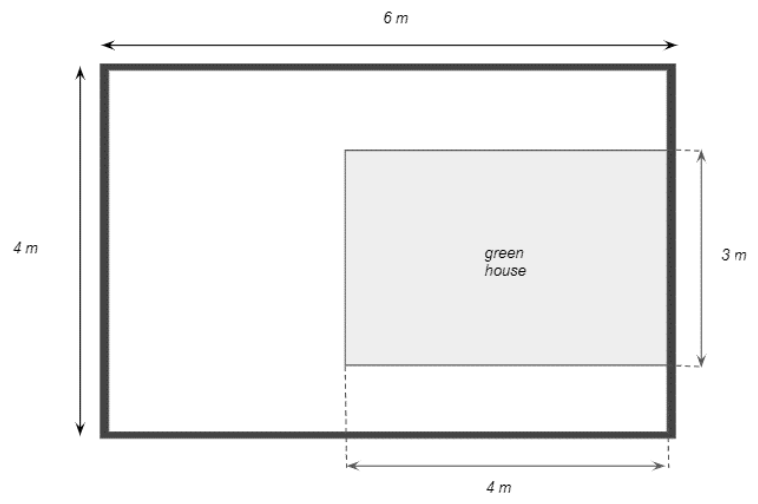

Source: (Data collection, 2020)

Figure 4: Floor Plan: Utilizing Rooftop as the Space
The types of planted plants vary, adjusted based on what she regularly eats daily, mostly vegetables. The types of vegetables she planted ranging from potatoes, chili, eggplant, bok choy, spinach, and tomatoes. As for the herbs and spices, she plants various kinds of leaves, such as mints leaf and bay leaf. Different kinds of plants require different cultivation systems and space needs. Small-sized plants like mints are planted in a small pot or polybag, while medium-sized plants require bigger containers.

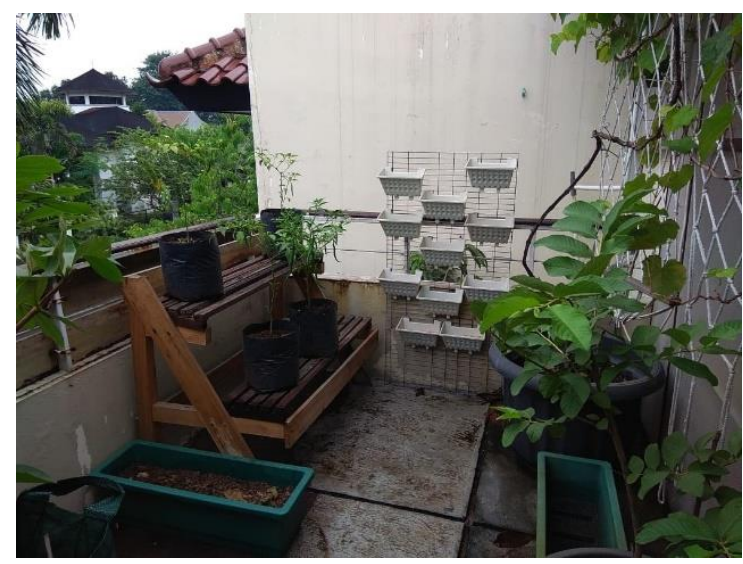

Source: (Data collection, 2020)

Figure 5: Variation of Pots Stacked Vertically Filled with Herbs and Spices Used by Tuti

The location of the garden is on the rooftop of the house and there is no solid ground or soil. Therefore, she adjusted the space and the type of cultivation system. She mainly uses big pots and polybags that are placed on shelves (Figure 5). This can save much space since the container is placed vertically, not horizontally. Other than stacking pots and polybags on a shelf, she also uses a net placed on the wall to support the climbing plants.

She started doing urban farming during this pandemic out of boredom, due to the lockdown. This results in spending more time at home with the family. She usually engages her family also to help her growing food, including her granddaughter. She usually waters her plant in the morning and evening. She spent around an hour in the outdoor area to take care of the 
garden. Other than watering the plants, she also likes to idly sit on the rooftop and enjoy the morning sun as it makes her feel a good mood throughout the day. According to her questionnaire result, all indicators that include happiness, satisfaction, and productivity are increased (Table 4).

Table 4: Average Level of the Indicators Before and After Doing Urban Farming

\begin{tabular}{|l|c|c|c|}
\hline Indicator & Before & After & Difference \\
\hline Happiness & 5 & 7 & 2 \\
\hline Life-satisfaction & 7 & 8 & 1 \\
\hline Productivity & 7 & 8 & 1 \\
\hline
\end{tabular}

Source: (Data collection, 2020)

Throughout the process, she feels happier after doing the urban farming activities. She feels happy when finding out that her crops are growing well. Increased level of happiness and satisfaction resulted in increased productivity level. After started doing urban farming, she can spend her time in the garden. It shows that the activity of her choosing, which is urban farming, can increase her productivity level in terms of the amount of activity done. Being in nature also makes her feel more relaxed, especially in the morning when she waters her plants while sunbathing.

\subsubsection{Case Study 2}

The second garden also utilizes the house's roof terrace. The house itself is a two-level house located in Cinere, Depok area. The planter or defined as the one who grows the plants is a 47years old woman named Devi. She lives in the house together with other 6 family members. She is currently working every day as a doctor. She has been doing this urban farming gardening since the pandemic started. The form of urban farming varies from hydroponic to pots and polybags.

The garden utilizes a terrace within the area of the house located on the upper floor. The terrace has a surface area of around $20 \mathrm{~m}^{2}$. The area itself has a dimension of $4 \mathrm{~m} \times 5 \mathrm{~m}$ (Figure 6). It is packed with various types of plants, ranging from herbs, spices, and vegetables. The space has a pentagon-shaped pond located in the middle. The size of the pond is quite occupying the space, considering it only left around 1-1.5 $\mathrm{m}$ between the edge of the terrace and the pond. Thus, maximizing the space is important in this case.

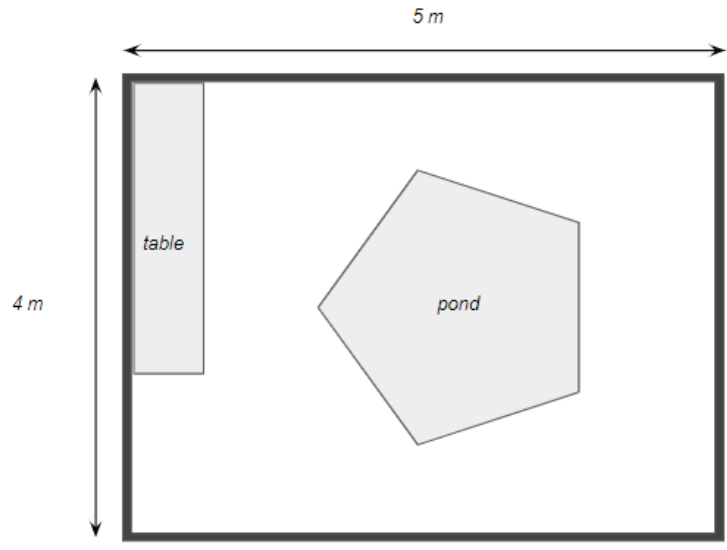

Source: (Data collection, 2020)

Figure 6: Floor Plan: Utilizing Rooftop as the Space

Accordingly, space consists of a pond, some pots, and polybags, a hydroponic system placed vertically and horizontally, as well as a semiroof structure that covers up the area (Figure 7). She uses hydroponic stacked vertically placed on the floor and also hydroponic laid out horizontally placed above the pond. She adjusted what type of plant to grow based on which plants she needs, as her main reason for doing this urban farming is for personal consumption. Bok choy, kale, green cabbage, bell pepper, and tomatoes are some of the vegetables that she planted. While for the herbs and spices, she has various kinds of leaves, such as rosemary, mint, coriander, and lemongrass. She revealed that growing plants such as herbs and spices are very convenient yet beneficial because they are used in almost every meal she cooks. 


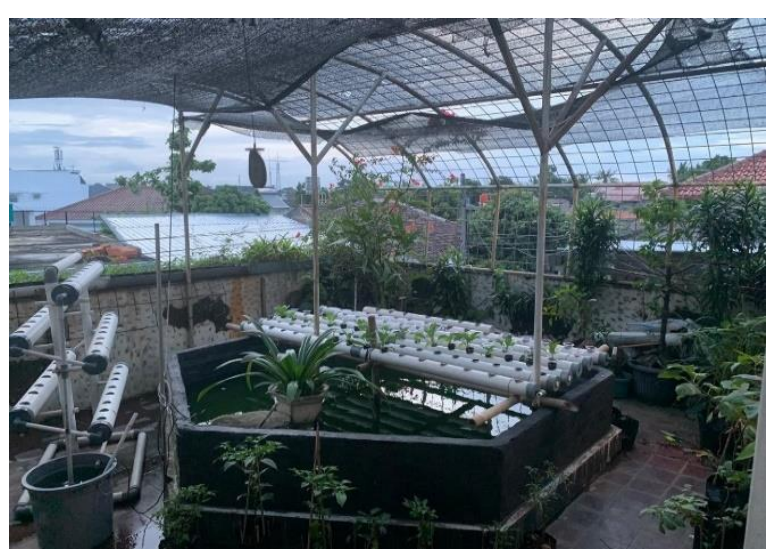

Source: (Data collection, 2020)

Figure 7: Overview of the Space

Due to the limited space, she tries to maximize the space as effectively as possible. Thanks to that quite big pond in the middle, she has the option to take advantage of the sidewalls. She uses a hydroponic farming system here with a styrofoam box to hold the water, which is called the raft aquaponic styrofoam board sheets system. This is an effective way to use a hydroponic system implemented in a limited space. Other than putting the aquaponic boards, the surface also serves as a place to do the seedling process before being put in a bigger container.

She declares that doing urban farming activity has many benefits, especially during this pandemic. Personal consumption is one of the main reasons why she started planting herself. Urban farming also provides a constant supply of fresh food, especially vegetables. Therefore, it can reduce her weekly expenses on buying groceries. Her questionnaire result regarding the effect indicators can be seen in Table 5 .

Table 5: Average Level of the Indicators Before and After Doing Urban Farming

\begin{tabular}{|l|c|c|c|}
\hline Indicator & Before & After & Difference \\
\hline Happiness & 5 & 8 & 3 \\
\hline Life-satisfaction & 7 & 8 & 1 \\
\hline Productivity & 8 & 8 & 1 \\
\hline
\end{tabular}

Source: (Data collection, 2020)
The data in Table 5 showed that her happiness and self-satisfaction level is increased along with her productivity level. During her activity of urban farming, she felt happiest when she can take care of her plant in the morning by watering it. Her level of satisfaction is also increased after accomplishing her purpose of urban farming. The feeling of satisfaction is resulted from being able to grow her crops and eat them. Overall, she feels happier after being outdoors and closes to nature.

\subsection{Discussions}

This pandemic has forced us to be at home at all times and Work from Home (WFH) has been applied to most people. Data from the questionnaire show that $47.8 \%$ doing a full WFH while $52.2 \%$ doing a partial WFH. This suggests that the home has become the center of daily activities. Accordingly, urban farming proved to be the choice of activities to do as indicated by the questionnaire result that 49 people have chosen to do this activity.

Using pot/polybags to plant crops is the most popular choice among the other types. As many as 60 people of the respondents choose to cultivate using a pot. This is also in line with the case study's result. The interviewees of both case studies are using pot as their main plant container. They are available in various sizes and this should be taken into consideration. Thanks to its flexible size, it can be placed in any area. Good space utilization can also be achieved by combining several types of urban farming as is the case in these two case studies. Other than pots and polybags, verticulture and hydroponic are also popular choices. Deciding what types of urban farming suited best can be defined by the space available, growing media, and environmental conditions.

In terms of the area size, limited and small space areas have always been the issue, especially when living in a densely populated city. These case studies focused on the garden 
within a surface area of 20-25 $\mathrm{m} 2$ located on the rooftop of the house. Utilizing an unused space within the house is the option when you have only a small space. The questionnaire results show that 37 people utilize an area of 1-10 m2 for urban farming. This proves that urban farming can still be done on a land of less than $10 \mathrm{~m}^{2}$. Therefore, the land limitation should not be the reason for not doing urban farming.

There are many theories which state that urban farming benefits not only the people but also the environment of the living space. Many theories declare that being in nature and seeing all the greeneries can lead to the improved wellbeing of the individual [31]. In both the questionnaire and study cases, the data collected regarding its effect on the people is based on 3 indicators, namely happiness, self-satisfaction, and productivity.

Urban farming allows the planter to feel an increased level of health and wellbeing as proven by the data collected from the questionnaire. It reveals that $100 \%$ of 74 respondents agree that urban farming makes you feel healthier and it increases your spirit. The data also shows that 72 respondents $(97.3 \%)$ agree that urban farming can reduce their stress level. And doing urban farming is accordingly considered to be the right activity during this pandemic time.

In terms of its impact on the surrounding environment, urban farming can provide greeneries to space. According to the data from the questionnaire, it showed that 73 people (98.6\%) agree that doing urban farming can make the space greener and more appealing. Other than that, data gathered from the study cases stated that the greeneries increase the value and quality of the space, both in terms of air quality and space utilization.

\section{Conclusion}

Before this pandemic, we are all used to doing daily activities outside the house for most of the day. Due to this pandemic situation, our activities are done mostly at home. Staying at home means commuting to work or other places is unnecessary. Consequently, we have more free times that can be spent through urban farming by utilizing the space available in our house.

Urban farming has become an interest for most people. This can be seen by the trend that keeps increasing throughout the year, especially during this unprecedented time. Many types of urban farming can be implemented in landed houses, such as hydroponic, aquaponics, pot/polybags, on the ground, and verticulture. The issue of limited land area has always been a problem for people living in densely populated urban areas. Hence, it is vital to maximize every inch of the house space and to use suitable types of farming.

Based on the data obtained from both the questionnaire and study cases, urban farming is proven to give a positive effect on the people and environment. The questionnaire result indicates that such an effect can be seen from 3 indicators, namely happiness, satisfaction, and productivity. According to the data gathered, all of them show an increased level when these indicators before and after urban farming are compared. In terms of its effect on the environment, having greeneries is proven to make the space greener and more appealing which leads to an increased value and quality.

Additionally, the data obtained from these findings also show the spaces that are used by the house occupants for urban farming. The data shows that the backyard is the top choice for gardening, while a surface area of $1-10 \mathrm{~m} 2$ is the most popular range of area used. The amount of space available affects the plant that you can grow. Therefore, considering the 
limited space, using the right types of farming, will increase how many crops you can produce. The limited space has always been an issue when people want to start practicing urban farming. However, this undergraduate thesis showed that land limitation should not be the reason for not doing urban farming since it can be practiced anywhere within your living space.

In conclusion, this study was taken during the pandemic in 2020 and urban society become the subject of this survey. Due to the limited activities of people living in urban area during the pandemic, urban farming become the choice of activity especially for people who have space in landed houses. This can be done by utilizing spaces located within the house area. While the effect of doing urban farming to the people ranges from the increased level of happiness, satisfaction, and productivity, in terms of the living space environment, it can also improve the value and quality of the space in questioned.

\section{Acknowledgement}

Thank you for all of the respondents and study case user who has provided permission and time for the authors to make observations that support this study.

\section{References}

[1] Sodhiq, A. Tren Urban Farming Meningkat di Masa Pandemi COVID-19. Sariagri. Retrieved; 25 November 2020, from

https://pertanian.sariagri.id/57754/tren-urban-farmingmeningkat-di-masa-

pandemi-covid-19.

[2] BPS. Persentase Penduduk Daerah Perkotaan menurut Provinsi, 2010-2035.

bps.go.id; 2020.

[3] Azwar, D. \& Ghani, I. The Importance of Green Space: Towards a Quality Living Environment in Urban Areas. Archnet-IJAR: International Journal of Architectural Research; 2009, 3. 10.26687/archnetijar.v3i1.267.

[4] Mc Gee, S. L., Höltge, J., Maercker, A., \& Thoma, M. V. Sense of Coherence and Stress-Related Resilience: Investigating the Mediating and Moderating Mechanisms in the Development of Resilience Following Stress or Adversity. Frontiers in Psychiatry; 2018, 9, 378. [5] Schmutz, Ulrich \& Lennartsson, Margi \& Williams, Sarah \& Devereaux, Maria \& Davies, Gareth. The benefits of gardening and food growing for health and wellbeing; 2014, 10.13140/RG.2.1.3703.5289.
[6] Mougeot, Luc. Urban agriculture: Definition, presence, potentials and risks.

Growing Cities, Growing Food: Urban Agriculture on the Policy Agenda; 2000.

[7] Bailkey, M., and Nasr, J. From Brownfields to Greenfields: Producing Food in North American Cities.

Community Food Security News; 2000. Fall 1999/Winter 2000:6.

[8] Wiyanti, A.N. Implementasi Program Urban Farming Pada Kelompok Sumber

Trisno Alami Di Kecamatan Bulak Kota Surabaya. Jurnal Publika; 2013. 1, 2, 1-15.

[9] Galhena, D. H., Freed, R., \& Maredia, K. M. Home gardens: A promising

approach to enhance household food security and wellbeing. Agriculture and

Food Security. BioMed Central Ltd; 2013.

[10] Maslow, A. H. A Theory of Human Motivation. Psychological Review;1943. 50(4), 370-96.

[11] Ozden, O., \& Laleci, S. Home Garden and Urban Ecology of a Mediterranean

City. International Journal of Current Research; 2017. 9(09), 57406-57408.

[12] Reed, R., Wood, C., Barton, J., Pretty, J.N., Cohen, D., Sandercock, G.R.H. A repeated measure experiment of green exercise to improve self-esteem in UK school children. PLoS ONE; 2013. 8 (7), e69176.

[13] Maneesha, S R \& gb, Sreekanth \& Rajkumar, Susitha \& Chakurkar, Eaknath. Urban farming-emerging trends and scope; 2019, 6. 709-717.

[14] Haletky, N. Urban Agriculture as a Solution to Food Insecurity. West Oakland and People's Grocery; 2006.

[15] FAO. The State of Food and Agriculture. Food Security: Some Microeconomic Dimensions; 1996.

[16] Hodgson K, Campbell MC, Bailkey M. Urban agriculture: growing healthy, sustainable places. Am Plann Assoc. Washington, DC; 2011.

[17] Landis, T., Jacobs, D., Wilkinson, \& Luna, T. (2014). A Guide to Starting and Operating a Nursery for Native and Traditional Plants. United States Department of Agriculture; 2014. (pp. 101-121)

[18] Sekhar, L. The Urban Farmer: 8 tips on growing your edible garden like a pro.

Optionstheedge.com; 2014.

[19] Sofo, A., \& Sofo, A. Converting Home Spaces into Food Gardens at the Time of Covid-19 Quarantine: all the Benefits of Plants in this Difficult and Unprecedented Period. Human Ecology; 2020, 48(2), 131-139.

[20] Harianto, B. Petik Sayuran di Lahan Sempit (1st ed.). Penebar Swadaya; 2017

[21] Paeru, R., \& Dewi, T. Panduan Praktis Bertanam Sayuran di Pekarangan (4th ed.). Penebar Swadaya; 2016.

[22] Rinkesh. What is Urban Agriculture? Types and Benefits of Urban Agriculture. Conserve Energy Future' 2020.

[23] Juniawati \& Hayuningtyas, M. Urban Agriculture Development: A Strategy to Support Food Security. In ICSAFS Conference; 2017.

[24] Felser, V. Success Factors of Urban Farming Projects in Europe: A Case Study Analysis (Master). Modul University Vienna; 2019.

[25] Santo, R., Palmer, A. and Kim, B. Vacant Lots to Vibrant Plots: A Review of the Benefits and Limitations 
of Urban Agriculture. Johns Hopkins Center for a

Livable Future; 2016.

[26] Frumkin, H. Healthy places: exploring the evidence. American journal of public health; 2003, 93(9), 14511456.

[27] Kaplan, R. and Kaplan, S. Restorative experience: the healing power of nearby nature. The Meaning of Gardens. MIT Press, Cambridge; 1990, 238-243.

[28] Konner, M. The tangled wing: Biological constraints on the human spirit. New York, NY: Henry Holt; 2002.

[29] Mind, Organization. Ecotherapy: The green agenda for mental health. UK: Mind Publications; 2007.

[30] Delagran, L. How Does Nature Impact Our Wellbeing? Taking Charge of Your Health \& Wellbeing; 2016.

[31] Ulrich, Roger \& Simons, Robert \& Losito, Barbara \& Fiorito, Evelyn \& Miles, Mark \& Zelson, Michael. Stress Recovery During Exposure to Natural and Urban Environments. Journal of Environmental Psychology. 11: 201-230. Journal of Environmental Psychology; 1991, 11. 201-230. 10.1016/S0272- 4944(05)80184-7.

[32] Veenhoven, R. Happiness: Also Known as "Life Satisfaction" and "Subjective Well-Being"; 2012, 10.1007/978-94-007-2421-1_3.

[33] Sousa, L. \& Lyubomirsky, S. Life satisfaction. Encylopedia of Women and Gender: Sex Similarities and Differences and the Impact of Society on Gender; 2021, 2. 667-676.

[34] Lohr, Virginia \& Pearson-Mims, Caroline \& Goodwin, Georgia. Interior Plants May Improve Worker Productivity and Reduce Stress in a Windowless Environment. Environ. Hort; 1995. 14. 10.24266/07382898-14.2.97.

[35] D'Alessandro, Daniela \& Gola, Marco \& Appolloni, Letizia \& Dettori, Marco \& Fara, Gaetano \& Rebecchi, Andrea \& Settimo, Gaetano \& Capolongo, Stefano. COVID-19 and Living Spaces challenge. Well-being and Public Health recommendations for a healthy, safe, and sustainable housing. Acta bio-medica: Atenei Parmensis; 2020, 10.23750/abmv91i9-S.10115.

[36] Gripsure. How to add value to your garden without spending a fortune. gripsure.co.uk; 2020.

[37] Pramana, E. Manfaatkan Waktu di Tengah Pandemi Bisa Lakukan Urban Farming. Jawa Pos; 2020. 